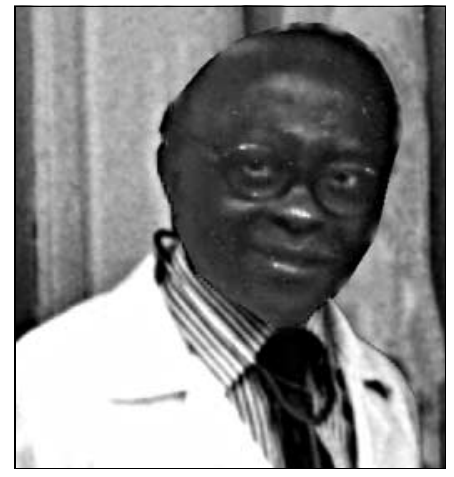

\section{Steven Bosa}

Formerly, inter alia, Advisor Psychiatrist to the Government of Uganda and the Ministry of Health

Steven Bosa was the first indigenous Ugandan African to train in psychiatry; he obtained his Conjoint DPM in 1960 after a period as a Clinical Assistant at the Maudsley Hospital. He had graduated in Medicine in 1946 from Makerere University College. He was elected a Foundation Member of the Royal College of Psychiatrists in 1971 and later a Fellow.

I first met Steven in February 1966 when I arrived in Kampala to take up a position as the Foundation Professor of Psychiatry at the Medical School of the University of East Africa. Steven was the only other psychiatrist in Uganda at that time. He was responsible for an astonishing range of duties and services, which included the provision of mental health services to all of Uganda and its 12 million people; the assessment of all persons sent to the secure forensic unit based at Butabika (known as the Broadmoor Unit); the management and administration of the Nurses Training School, also based at Butabika; and also, until my arrival, he had provided clinical and theoretical teaching to the medical students of Makerere Medical School. In addition, he was the only and much respected advisor in matters of mental health to the Government of Uganda and its Ministry of Health.

He had fought hard and effectively for the establishment of a Chair in Psychiatry at Makerere. Until, as early as 1952 , having been given the responsibility of finding a suitable site for a 'modern mental hospital' in Uganda, he not only identified the Butabika site, but secured this splendid piece of ground in the face of competition from developers and various other government ministries.

Physically he was a small, compact person, quick and agile in his movements, who expressed emotion with his whole body and facial expressions. He set and insisted on maintaining high standards in his clinical and administrative work and I soon became personally aware that when a visit from Dr Bosa was due at the Ministry of Health in Entebbe those expecting to see him were in no doubt that their performance or lack of it would not escape his sharp eye.

In the course of his lifelong preoccupation he started and sustained the Psychiatric Nurse Training School at Butabika Hospital, a concept which he introduced to the Government in 1960. When deserted by the flight of expatriates, psychiatrists and other mental health specialists in the face of a rampaging Idi Amin in 1972-1973 and 1974 he managed, in the face of all odds, to keep a central and rural service going by careful deployment of his devoted nursing personnel. Later, after his formal retirement in 1973, he managed to convince the Ministry of Health to set up a Psychiatric Clinical Officers Training School, again at Butabika, which saw its first intake during the turbulence of 1979 when the Amin regime was in a state of terminal collapse. These clinical officers are now responsible for running community-based mental health services in every corner of Uganda.

He suffered from a flying phobia throughout life. As a result he travelled only as far as he could by road. The exception, of course, was his emergence to train in the UK, an experience which he held dear, as if the Holy Grail of his achievements, talking often when frustrated of "going home to London". But he never did.

He died in Kampala, Uganda in February 2000 , at the age of approximately 80 years.

\section{G. Allen German}

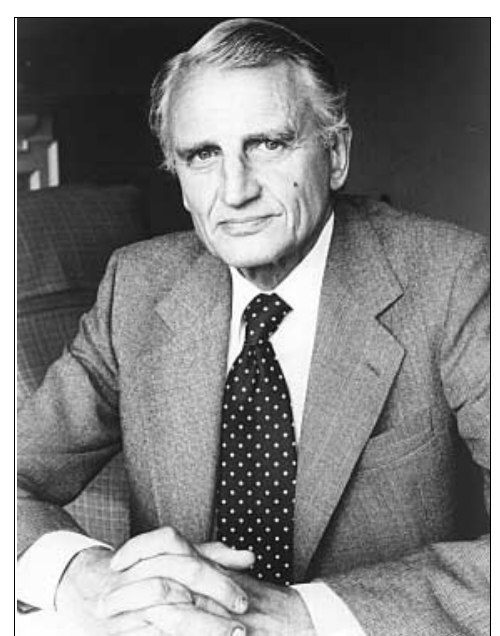

\section{Robert (Bob) Gosling OBE}

Formerly Chairman, Tavistock Clinic, London

Bob Gosling, who died aged 79 years, was in his day one of the most influential psychiatrists in the country - being both a psychotherapist to many professional colleagues and their spouses, and an inspiration to generations of colleagues and students at the Tavistock Clinic

The Tavistock, founded in 1920, had always been a centre of excellence, albeit perceived as a somewhat eccentric one with its early emphasis on multidisciplinary partnership and on the importance of psychosocial factors. During the Second World War many of its staff served in uniform and were centrally involved in Army psychiatry, and in particular the War Office Selection Boards that still form the basis of Civil Service selection in the UK. Following the War many of the staff, including John Bowlby, Wilfred Bion and Jock Sutherland, among others, returned to the Tavistock and proceeded to run the place on somewhat military lines.

Bob Gosling was the first and foremost of the new generation of psychiatric staff that shaped the Clinic following the retirement of Jock Sutherland as chairman. His style was a much more facilitating and participatory one, and led to a flowering of creativity in the institution.

Gosling led the Tavistock Clinic from 1968-1979, and during this period crafted the strategic vision that has been implemented since then. His emphasis was determinedly on valuing the contributions of all members of staff and of all disciplines equally. In this he followed the ideals of the Clinic's founders, but at a time when medical supremacy was the norm. He went far beyond the training traditions of the day in believing and acting upon his views that psychiatrists had a great deal to learn from other mental health professionals.

Born in Birmingham, Gosling became a medical student there and obtained a BSC in physiology. He then gained a Rockefeller Scholarship to do his clinical training in the USA, at Cornell. After obtaining his $\mathrm{MD}$ at Cornell, and qualifying on his return to the UK, he worked as a locum general practitioner before starting his psychiatric training at the Maudsley Hospital as registrar to Professor Sir Aubrey Lewis.

He then became a senior registrar in the adult department of the Tavistock Clinic, acting for several years as assistant to the psychoanalyst Michael Balint, who was pioneering training for general practitioners. Gosling qualified as a member of the British Psychoanalytic Society in 1958, and became a consultant at the Tavistock Clinic.

Bob was much loved by his patients and colleagues for his warmth, tolerance and deep understanding of the vicissitudes of the human condition. He himself acknowledged that his own suffering and experience 
as a patient, of which he had more than his fair share, moulded his attitude to patients, colleagues and to life in general.

As a medical student in the USA he developed tuberculosis, from which he suffered for four years, much of which he spent flat on his back. He often spoke of how deeply impressed he was by the observation that whether his fellow patients got better or worse depended to a significant degree on their emotions - a finding that he not only applied to himself, but that moved him towards a career in psychoanalysis

He was unfortunate to be given a 'second dose' of such learning when he developed poliomyelitis during his training as registrar at the Maudsley and spent 18 months off work, several weeks of which he spent in an iron lung. He later spoke of his state of mind of helpless dependency at this time, and of the importance of his relationships with staff looking after him, including the ward cleaner who seemed to be very energetic with her broom around the life-saving electric plug on which he was dependent!

These experiences, and his analysis with Wilfred Bion, also gave him a lifelong interest in group and institutional processes. He was very influential in the design of many training courses, both at the Tavistock and elsewhere, ensuring that they harnessed the innate group dynamics available for learning.

With colleagues such as Eric Miller, Gordon Lawrence, Pierre Turquet and others, he was strongly involved in the Leicester Group Relations Conferences that brought together professionals from fields as far apart as health, industry and government in order to study matters of leadership and authority in organisations, and significantly stretched the boundaries of understanding with his classic paper on very small groups. He was also centrally involved with the work of the Royal College of Psychiatrists, and organised the enormously successful 1964 International Conference on Psychotherapy.

In late middle age his hearing failed, and he decided to take early retirement from the NHS. In recognition of his work he was awarded the OBE.

He and his wife, the novelist Veronica Henriques, retired to Gloucestershire. Together they restored a Queen Anne house, and he took up his hobbies of carpentry and part-time farming. He never lost his capacity to support friends and colleagues alike, and did so till his last few hours.

He is survived by his wife, four sons and a daughter.

Anton Obholzer

\section{Ben Porges}

Endowed the Foundation Chair in Old Age Psychiatry,

University of Manchester

Ben Porges died on 6 December 1999. He was an engineer by training who founded a company, Flexibox, which became widely known and widely respected in the engineering field, in particular in relation to oil pipelines. His contribution to psychiatry will not at first be obvious to readers of this journal, but he endowed the Foundation Chair in Old Age Psychiatry in the University of Manchester. His wife, Marianne, died of Alzheimer's disease and it was to honour her memory that he funded the Chair. He kept an active interest in the field and used his connections to further research funding.

When university and health service money is tight, endowments like this are a welcome and a necessary vehicle to fund academic developments. It is poignant that a contribution like this should grow out of such personal tragedy but this makes the contribution even more significant in personal terms.

Alistair Burns and David Jolley 